\title{
FEMALE CIRCUMCISION: MOPOLIHU LO LIMU AND MONGUBINGO CUSTOMS IN BUILDING LEADERSHIP BEHAVIOR
}

\author{
Lisdawati Muda \\ IAIN Sultan Amai Gorontalo \\ Email: lisdawati02muda75@gmail.com
}

\begin{abstract}
This article discusses the custom of female circumcision for the people of Gorontalo, carried out for generations. The procession of female circumcision custom process has its symbol, meaning, and purpose, that expects every circumcised girl to be a religious woman, useful for family, community, nation-state life. Besides, she is expected to have a responsible and trustworthy leader spirit. The role of women as leaders and how to behave in leadership is reflected in the custom practices of female circumcision. The results showed that in the perspective of the Gorontalo community, the female circumcision tradition is an obligation because of its values as a translation of religious importance. The persistence of Gorontalo people to always preserve this tradition is maintained, even though some scholars and communities view that female circumsicion is not a compulsory matter.
\end{abstract}

Artikel ini membahas mengenai adat khitan perempuan bagi masyarakat Gorontalo yang dilakukan secara turun temurun. Urutan prosesi adat khitan perempuan memiliki lambang, arti dan maksud tersendiri, yakni mengharapkan setiap anak perempuan yang dikhitan menjadi perempuan yang taat beragama, bermanfaat bagi kehidupan keluarga, masyarakat, bangsa dan negara. Selain itu, mereka diharapkan berjiwa pemimpin yang bertanggung jawab dan dapat dipercaya. Peran perempuan sebagai seorang pemimpin dan bagaimana berperilaku dalam memimpin tercermin dalam tata cara adat khitan perempuan. Hasil penelitian menunjukkan bahwa dalam pandangan hidup masyarakat Gorontalo, adat khitan perempuan adalah suatu kewajiban karena nilai-nilai yang terkandung 
di dalamnya merupakan penjabaran nilai-nilai agama. Keteguhan masyarakat Gorontalo untuk selalu melestarikan adat khitan perempuan tetap terjaga, meskipun dalam pandangan sebagian ulama dan sebagian masyarakat khitan perempuan bukan merupakan perkara wajib yang harus dilakukan.

Keywords: female circumcision; leadership; tradition

\section{Introduction}

Nation-state development is a changing process, improving and developing the state progress conducted with a keen awareness and prepared comprehensively based on the planning toward better and modern nation state life. The directed and sustainable development implementation is a responsibility for every individual and all community elements, including women that also involved in every social activity and various leadership activities to achieve the development goals.

One of female roles and responsibilities today can be seen from women's involvement and role in leadership (Astuti, 2019). Women leadership has a particular method and slightly different from men leadership method. Because, women have characteristic by nature such as menstruation, pregnancy, childbirth, and breastfeeding that can ask other people to do command under their motivation and expectation. The women's leadership stayed on function, authority, and obligation of each individual to persuade and ask others to implement the instruction, complete some works and responsibilities based on truthness and justice principles. According to Islam, women may take a leadership role if they are able and having the capability to occupy the position intended.

Women also have some activities that tend to social roles, culture, economics, etc. In the family as the smallest environment, leadership is not only male responsibilities but also females (Amin, 2018). Women are directly responsible and having an active role in managing family and household for achieving the sakinah, mawaddah wa rahmah family. Hadits Rasulullah SAW says: "Every Eden offspring is a leader, thus male is family leader, and female is the household leader" (HR. al-Bukhari).

Leader does not differentiate between male and female. Therefore, foundation of their struggle is looking for the opportunity and the same right for every individual including female based on the equity of existence as the creature of Allah SWT in the social community environment and various 
fields (Mufidah, 2008). The essential of leadership is a duty for everybody to reinforce the truth and justice. Leadership is not based on power, facilities such as a luxury car, official residence, more lumpsum of occupation, and many policy access without giving attention to the other people's rights.

Women also have a role and responsibilities as a leader in every level, both in institutions of government, private, and social organization, even to become leader in the battlefield. Women leadership is not only in household environment in meaning to persuade men to recognize their right, but women role in administration also has the same opportuniy and right to participate in various social organization and environment or other community environments. Those roles are realized in the form of active participation of female as people representative, head of village, regent, major, governoor, ministry and even president. It shows that women can contribute to development in realizing the equitable social justice for the nation-state victory.

Some people have opinions that women do not have the capacity to be a leader in various sectors and organization, particularly to become leader of nation state. They assumed that their ability, especially for career women balancing with their domestic jobs, characterizes weak and indecisive personality. Novianti (2016) argued that one of restriction encountered by married women when she entered into public sector and leadership activities is the women tend to ignore the parenting issues. All duties of household will be given to house assistants to educate children. Other negative aspects associated to working mothers are not dare to take decisions, easy to give up, unlogical, emotional, tending to believe mystical etc.

Beside differences of opinion about women leadership, some people have doubts for successful women leadership, because many women leader got cases of drugs, corruption, persecution, fraud, infidelity, adultery, destruction, and other issues. Ahmad (2019) looks at many instances, particularly corruption case often happening and involving women leader. The corruption case has been assumed to reduce integrity and public trust values for women leadership in Indonesia in the future. Women leader that get corruptor status will give the negative image for women leadership in organization and community in various sectors.

The issues above become the responsibilities for all community components, such as figures of religion, community, tradition, youth, educator, etc. In some areas including Gorontalo that still strongly hold the local culture and tradition, they always use a discussion approach to resolve some cases. 
According to Arpin and Haritsa (2018) the custom approach by discussion can be used as alternative for resolving disputes. It is carried out by harmonizing between the effects of small criminal and civil action. The method was done by mediation.

Gorontalo is one of the cities in Indonesia where the Moslem still firmly hold the local culture and custom. Gorontalo people were known as loving local culture and tradition and also assuming the local custom as the honor that always kept with hereditary. Amin (2012) said that Gorontalo had four aspects of customs, such as tradition of visitor welcome, coronation, marriage, and funeral. Gorontalo also has procedure of akiqah, circumcision, etc. These aspects are conducted following the phylosophy of local Gorontalo, that is "tradition with principle of sharia, and sharia with principle of al Quran" or in Gorontalo language is called as "adati hulahulaa to syaraa, syaraa hulaahulaa to Qur'ani (Botutihe \& Daulima, 2003). It is also with the form of oral literature, dance, handicrafts, local traditional clothing, and so on, which have very high artistic value created to describe the beauty, wealth, comfort, security as well as the friendliness and politeness of its inhabitants.

Women's leadership in Gorontalo is not a big problem that is always debated if it has followed the requirements according to custom provisions. For example, a woman who is appointed as regent, or becomes the wife of a regional official such as mayor, governor and others is more likely to get recognition from the community through the coronation procession. In addition to the coronation custom, she should also undergo rituals of mopolihu lo limu and mongubingo, that is a series of practices for female circumcision in Gorontalo (Djibu et al., 2014). This custom illustrates the phase of a woman's life that starts from infancy. Until she entered adulthood, she is expected to behave gently, be virtuous, graceful and grow according to her nature as a woman. Also, the implementation of custom of mopolihu lo limu and mongubingo, contains religious values, which are essential for human demands. Gorontalo people generally realize how important the dimensions of ethical values in all traditional ceremonies. Therefore, the tradition procession of mopolihu lo limu and mongubingo has essential value and meaning that can be a corridor for every community that is doing this tradition. Another value contained in the custom is Islamic culture value that conducted and defended by Gorontalo people until now as the evidence of Gorontalo people's love for local tradition and culture (Djibu et al., 2014).

Mopolihu lo limu and mongubingo custom as the focus of the discussion is a series of Gorontalo customs in the form of bathing with lime followed 
by a procession of female circumcision. The activity is one of the processions customs that still causes controversy in a small part of Gorontalo society because it is considered hurting women (Isroqunnajah, 2008). This paper describes the female circumcision customs in Gorontalo and their implementation of building leadership behavior. It starts from the assumption that despite differences of opinion about female circumcision, in the view of the Gorontalo traditional community, it is an obligation to maintain the dignity and respect of women in Gorontalo.

\section{Literature Study}

\section{Leadership and women leader concepts}

Jurdi (2010) explained that leaders have some values, such as honesty, noble deeds, and consistency between what spoken and the social behavior. But, in many cases, a leader that occupies a position in government is only limited in the occupation period. Appreciation and respect of people or followers are only happening when they hold their position.

Women leader is always becoming a model for other people or their followers for always defending values of honesty and justice. Tombuu (2011:25) explained that leaders should realize that their duty is inseparable from the task of making decision. On that position, consideration and analysis for impact as an effect of decision result should pay attention to truth and justice.

A leader must be able to make alternative transparently about goals and usefulness of the decision taken, and the way to improve effectiveness of duty implementation as effort to accelerate completing the process. It is also necessary to ascertain knowledge about duty and responsibility of leader as decision maker. As decision maker, the leader must be able to make sure the alternative through some information collected. The interpretation will become a consideration for deciding what to do. The next steps are implementing the decision made and stipulated based on consideration and holistic analysis from various information, thought and other consideration. It is assumed more benefial for common need, based on values of honesty, truth, humanity and responsible.

Women leadership is basically to have a particular model in resolving the duty and authority. Based on their gentle nature, women leadership usually starts to know and feel in family environment, such as caring for children, care and loving. Women's behavior is identified with natural atributes, such

el Harakah Jurnal Budaya Islam Vol. 22 No. 1 Tahun 2020 
as sensitive, emphaty, like to care, cooperative and accommodative (Samani $\&$ Harianto, 2012). If those behavior implemented in an organization, leader can make the organization activities process becoming effective in achieving goals. It also shows that women can be responsible for leadership to get more achievement. Women leadership is not rare getting greater success than ordinary administration. It is caused by supporting ability through getting education, experience in organization and motivation from other women (Geotimes, 2017). Generally, leadership is technique or strategy conducted to embed confidence and loyalty of follower for their leader. Commitment and determination will be shown through firm intention to do various duty and instructions given by a leader. According to Prasetya (2019), the strategy implemented to become women leader included self autonomy and quality.

On self-autonomy aspect, the women involved in leadership should start by seeing some previous success of women leaders through political socialization theory. Political socialization emphasizes on family and parent as determinant of children success to involve in civic life. On the self quality aspect, the women leader can minimize various issues about gender in the leadership. To reduce those issues requires the women's active role or participation in some scientific forums, and contribute to behavior that streamlines the women leadership role.

Women leadership becomes crucial in developing process. Makmur (2009) stated that development is an activities process conducted by individual, group, organization, government, and nation state to create growth and dynamical that can create stability in increasing community life well-being. It involves all people including women without discriminating social status, economy, ethnics, and race.

Responding to national development concept, the government specializes in women's role in development. First, on education unit program; the government emphasizes on regulation regarding 12-year compulsory education with giving enormous opportunity to children from pre-welfare households through Smart Indonesian Card (Kartu Indonesia Pintar) and Family Hope Program (Program Keluarga Harapan). Second, on health unit program; the government prioritizes improving facilities to support the health service quality for women, children and teneegar, with improving and fulfilling nutrition. Third, on employment; the government centralizes on expanding of job opportunities, implementing salary payment regulation following technique or market procedure. The government also intensifies to increase skill and capability by giving training for women with strenghening application of regulation regarding recruitment 
of man power that emphasizes on equality of right among men and women. Fourth, the government socializes the violance danger for women and the danger to hire women illegally, mediate women which experiences a violence cases through legal protection (Khumairo, 2019).

Poenk (2016) describes that the women's function is strongly influencing development dialectics to make the nation state becoming more modern and respected by other nations. However, it still has problem on how to revive children and teenage women awareness for their role as state development cadre. Therefore, the woman should have an awareness of her role starting from the family environment, as a mother, and in the nation state life which their right could be equivalent with man. The women role in community and nation state life can be implemented based on the skill and expertise.

Prantiasih (2016) has also argued that women have a significant role in community, starting from household environment, family, and even public purpose. They must protect their family, particularly children and family member, in resolving the entering of communication and information flow that makes worrying in bringing negative impact to the family value order. It will be able to keep and grow the moral value order in family life.

In public or community social field, the women should be able to participate actively in various sectors as efforts to respond the development of digital era today. However, some people still assume that women's participation in various fields not much expected and tends to ignore more the ability to socialize, or many people do not involve women in all activities aspects. The assumption was encouraged by a pessimistic feeling on women's skill, particularly in managing and leading organization. Besides, women leadership is identified with less accurate and ineffective in making decision because women are limited in managing time, preparing power, thinking, having the issue of power struggles, etc. In the household domain and family, the women can become pioneers in creating a safe, secure, and prosperous life through an effort to create interaction among the family member. Women who have expertise in managing family and social community organization and skill in leadership will have the right to become community leaders, organizations, and even national leaders (Makmur, 2009).

Women have the same right with men in participating in leadership activities while they are capable, trusted, skilled, smart and competent. Their capability and skill owned enable them to do various leadership activities aspect. The capable and intelligent women leadership can be achieved through formal 
and informal educations. The capability in supporting leadership activities, according to Samani and Hariyanto (2012), is capability in critical thought and problem solving, communication, creative and innovative, collaboration, cooperation, and capacity in contextual learning. Women should also have a function of professional attitude, trust, ethics, accountability, adaptability, personal productivity, personal liability, ability as human, self-control and self-sufficient to be able giving role in development.

Concerning with the arguments of Samani and Haryanto (2012), accordingly, women need to unite three bits of intelligence domain for doing leadership activities, such as Intelligence Quotient (IQ), Emotional Quotient (EQ), and Spiritual Quotient (SQ). The women should learn and develop continuely those three intelligence domain without ignoring one field only. Because the smart leader emotionally starts from bright in thought, the intellectual quotient leader can read and count the impacts assumed, perceived, and conducted. The smart leader intellectually without having emotional quotient tends to be not wise and challenging to accept other opinions. Spiritual quotient will play a more significant role in developing knowledge about meaning, and leader needs to conduct something to achieve the target and goals expected.

Women leadership emphasizes on protecing and loving others, but they should be assertive to take decision that starts from family environment, giving the position to working partner, active and participate directly in completing duties related with women roles (Affiah, 2017). Women leaders should also give trust felling and a significant opportunity to others to develop a career and profession. Thus, the women's leadership role can make a real contribution within development which starts from family enviroment, community, religion, and nation state.

\section{The Nature of Women Circumcision (Khifadh)}

Female circumcision has got serious attention from many countries around the world since long time ago, based on its relation from point of view of religion, gender, and health. Many experts from various areas, such as figure of religion, health practitioners, academicians etc. have analysed the impact of female circumcision. According to WHO (1997), the female circumcision consists of four categories. First, clitoridectomy is the cutting of clitoris or skin covering the clitoris. Second, excision is the cutting of clitoris and cutting part of labia minora, with or without cutting part of labia majora. Third, infibulation is cutting part or all outsides vagina and 
also stitching/narrowing the vagina, with or without clitoris cutting. Fourth, all other procedures conducted on vagina for non-medical aiming, including stabbing, perforation, slicing, and scraping for clitoris.

In Indonesia, the female circumcision is not conducted like in Africa by cutting all vagina. The Indonesian female circumcision applied with symbolic, it is suggestive only, without the real cutting of the vagina. Although, some shaman baby or traditional midwife argued that the female circumcision should be bloody around clitoris although only a little in labia minora part (Mustaqim, 2016). The shaman baby put the scissors, knife or razor blade on clitoris, scratching or stabbing a little on the clitoris, touching or cleaning the clitoris with fresh turmeric or moringa leaves.

From the definitions of female circumcision as explained shortly, it can be said that the female circumcision in Indonesia is not the same as circumcision in Afrika. It is not a harmful treatment based on health, although there is difference of female circumcision implementation in each area. The female circumcision in Indonesia usually conducted by shaman baby or or paramedical staff.

Female circumcision conducted by shaman baby is without involving medical staff based on Circular Letter issued by Directorate General of Community Health Education of 2006 regarding prohibitions of women curcumcision medicalization for medical staff (Inayati et al., 2016). It said that medical staff may not help anything related to female circumcision practice as commitment to protect women's right for all descrimination form, including violence for women. Through Ministry of Health, Indonesian Government issued again the regulation concerning female circumcision. Regulation of Indonesian Ministry of Health number 6 in 2014 concerning female circumcision on article 2 gave mandate to Consideration Assembly of Health to publish establishment of female circumcision that insures the female safety and not doing a female genital mutilation (Regulation of Ministry of Health, 2016).

Nashichuddin (2010) suggested that female circumcision is different from male circumcision. It is discussed openly in community environment. According to medical, the male circumcision is more accepted because it is useful in its practice. But, the female circumcision is different; it has got many critics because its benefit is not clear. Therefore, there are two assumptions in Muslim community to ascertain the female circumcision tradition: female circumcision as ancient tradition before Islam came that needs a review of

el Harakah Jurnal Budaya Islam Vol. 22 No. 1 Tahun 2020 
its useful, and there is also the assumption that female circumcision is part of Islamic teaching.

Some people who wonder about the female circumcision is feminist group and also ulema. Feminist see some cases of female circumcision in African countries. They argued that female circumcision should be stopped because it is harmful to women (Maisarah, 2015). It even results in mortality. Therefore, these groups, with some NGO campaign continually the danger of female circumcision. WHO has also supported this campaign.

Ulema rejected the female circumcision tradition based on validity of this teaching. They wonder of female circumcision, because Al-Quran does not explain a single verse about female circumcision tradition. If there is Hadits Rasulullah SAW teaching female circumcision, they will still doubt about the validity of those hadits. Therefore, ulema persuade the people not to do female circumcision. However, referring to Islamic fiqih, the female circumcision got strong support. It can be seen from some opinion of four prominent madzab figures in Islamic fiqih (Imam Maliki, Imam Hanafi, Imam Syafi'i and Imam Abu Hanifah) concerning the law of female circumcision (Khatijah, 2014).

According to Khatijah (2014), different opinion of ulema about law of female circumcision is an effect of differences about analysis of fiqih experts that emphasizes on the study based on text only. This response becomes foundation for deciding to sound the opinion about law of female circumcision that is only centralized on consideration obtained and studied from literature without seeing in depth in terms of female reproduction health. The circumcision implementation for men and women have given a meaningful use both physical health or mental health under shariah.

Imam Syafi'i and his follower assumed that female circumcision is an obligation. Its fundamental norm is similar to men circumcision, that is following the teaching of Prophet Ibrahim. The law of female circumcision is based on male circumcision law. Because, male circumcision is sunnah, then female circumcision is also sunnah. As for the act of female circumcision is mustahab (assumed good), as Imam Hanafi's follower and some of Imam Maliki and Imam Hambali's follower said. Other ulema also argued like this based on hadits Nabi Rasulullah SAW, "circumcision is sunnah for male and it is assumed good for female” (Khatijah, 2014).

Three opinions about female circumcision above are the result of ijtihad of classical ulema that strongly influenced by context at that time. Support of 
ulema for this female circumcision tradition is universal, because the meaning of people culture at that time put women in subordination position. Women as wife candidate must be holy and having the sign of holiness before marriage. Therefore, part of women organ that is sensitive (peak of clitoris) should be circumcised, so that it is not easily stimulated and misled into evil that breaks the holiness.

\section{Research Method}

This study was conducted by using a descriptive qualitative method, based on level of interest, problem urgency resolved on social context in the value form, cultural, faith, law, and custom. It used technique of interview, observation, and documentation to get data and information related to mopolihu lo limu and mongubingo tradition in building leadership behavior.

Interview technique in this study is as central data resource to know in-depth about the activities conducted during the process of mopolihu lo limu and mongubingo tradition. The custom figure becomes informant about the meaning contained in the implementation of this custom. Interview with the educator figure was about the education values contained in female circumcision custom. The government element was interviewed about the meaning of Gorontalo's tradition and cultural in building leader behavior and effort and steps taken by government in conserving local customs and culture of Gorontalo. The interview with the community figure concerned with people's roles and contributions to local custom preservation. Also, the interview was done with shaman baby or doer of female circumcision about steps of preparation and circumcision process.

The researcher did observation technique in Tilongkabila District, Bone Bolango Regency, Telaga, and Tinelo Districts Gorontalo Regency, Gorontalo Province. The researcher is not involved directly in observation activities on female circumcision process, but only observed and listened to something related to mopolihu lo limu and mongubingo tradition.

Documentation technique is done when the researcher collected data from various resources, like photos of mopolihu lo limu and mongubingo tradition, bulletin, magazine, scientific literature and file. The technique of data analysis in this research uses interactive model that contains four main analysis components that starts from collecting data, data reduction, data presentation and drawing conclusion.

el Harakah Jurnal Budaya Islam Vol. 22 No. 1 Tahun 2020 


\section{Female Custom in Building Leadership Behavior}

Female circumcision in Gorontalo is a tradition since ancient time. It has deep meaning for Gorontalo people that described by action during custom procession of circumcision. In the local language, the female circumcision procession in Gorontalo consists of a series of mopolihu lo limu and mongubingo tradition. It is quoted in the book by Botutihe \& Daulima, 2003.

Mopolihu lo limu is a tradition that is compulsory. It aims to clean the girl herself. Mongubingo is an obligation of sharia or female circumcision to clean female genital from unclean glands carried from birth. Concerning the point of view, another thing that asserts the importance of female circumcision is obtained from parent and custom figure information of Gorontalo, where female circumcision is culturally conducted since ancient times. Circumcision for girls is symbol of holiness and honor for female. If the girl born is not circumcised, then her offspring will bring haram, although from the legal marriage. Because the nature of female circumcision for Gorontalo people is self cleaning of the girl that conducted entirely by custom. The self-purification of girls led wholly based on Islamic sharia, both physically and mentally will be done by village midwife (hulango).

The village midwife appointed as organizer of mongubingo tradition should meet requirements; (a) Islam; (b) knowing procedure of mongubingo; (c) knowing words given by ancestors in doing female circumcision; (d) recognized by people as village midwife; (e) imam (hatibi) that reads prayer and shalawat (mongadi slawati) and (f) a mother that assumed elder as supervisor of this event. The female circumcision process is conducted following mopolihu lo lolimu custom (bathing with lime water). The attributes of custom/cultural object prepared consist of:

1. Taluhu yilonuwa (water of lime) with ingredient, such as: seven limes cut into two but not squeezed, the slice of seven kind of puring leaf, fragrance ingredient such as yilonta, onumo leaf, a type of mayana, jasmine flower called as moputi.

2. Seven yellow tube bamboo that covered by puring leaf and filled water and coin valued as Rp. 100, in ancient time called as 10 cent.

3. Bulowe, (betel nut, a sprig which is still closed and a sprig has bloomed) Bulowe, which has bloomed, hung on the seat of the mother with her child when bathed.

4. One fresh kampong chicken egg. 
5. Dudangata (coconut grater as the seat for the mother and her baby).

6. Hulante, (set of tray contained seven cup of rice, seven eggs, seven nutmeg and cloves, and seven coin valued as Rp. 100,-

7. One plate of alawahu tilihi (finely shredded turmeric mixed with whiting) and applied to the forehead, neck, throat, shoulders and grooves of the hands and feet.

8. Set of tray contained glass with small axis to light which called as tohetutu, and five cups of colored rice called as pale yilulo.

In doing mongubingo (circumcision) process, the atribute/cultural object prepared is:

1. Alumbu moputi'o (two meter fabrics, to cover the children head when circumcised)

2. Set of circumcision tool put on the tray, on a white cloth, it is small knife, and yinula monu (fragrance oil)

Custom atribute/cultural object and the steps conducted on mongubingo (circumcision) are as follows:

During mopolihu lo limu (bathing with purut orange ingredient) event:

1. Taluhu yilonuwa, or water of bathing with lime, consists of various components that means seven kinds of nature needs to removed since her growth, these are:

a. Nene'alo, means annoying behavior

b. Wetetolo, means evil speaking

c. Kekengolo, means busy behavior

d. Kureketolo, means carelessly practice and speaking

e. Pa'ingolo, means like denying to parent

f. Bulabolo, means like to cut speaking other with gibberish

g. Hutatingolo, means speaking with rough behavior

2. Limututu (lime) which is dominant on water of flower, it means to remove the seven bad habits.

3. Seven yellow bamboo tubes. These mean to obtain significant needs to self-purify from birth sin conducted by seven organ. They are: mouth that can lie or ghibah, eyes that can see forbidden thing, ear that can listen to bad speaking, nose that can rise hate feeling, foot that can walk and do bad stuff, hand that can break and genital that can have adultery. Coin entered into tube, it means the halal property.

4. Bulowe means the fundamental life in their existence in the world as the holder of mandate from Allah. 
5. Egg means the beginning of human

6. Dudangata (grated coconut) as cha ir mea n s kept away from crime.

7. Hulanthe, means:

a. Three liter of rice involves three stages of human life, rice symbolize subsistence.

b. Seven limes mean seven natures must be purified (pohinggi uhiluwiluwita)

c. Seven nutmeg and cloves means inner level that must be refined (lamahu lo batini)

d. Seven coin valued Rp. 100,-- means always looking for a property as life supporting.

e. Alawahu tilihi (mixture of shredded turmeric and whiting). It shows as; (1) giving a marking on the forehand means a statement not to worship other than Allah; (2) marking on the neck is a statement not want to eat illegal food; (3) marking under throat is a statement of maintenance of breathing in and out with dzikir everytime; (4) marking on shoulder as a statement of responsible for mandate of Allah; (5) marking on the curvature of the hands and feet as a statement will not do despicable acts.

f. Glass of tohetutu, means life shining, five kind of rices mean: (1) red rice symbolizes red blood on body, (2) white rice symbolizes white blood on body, (3) black rice symbolizes flash on body, (4) yellow rice symbolizes marrow on body, and (5) green rice symbolizes existing veins in the body.

The mopolihu lo limu as the begining stage of procession is continued by mongubingo. The object of cultural used in mongubingo stage has a meaning as follow:

1. Alumbu moputi'o (two meters white fabric), it symbolizes chastity curtain, it means the way to purify the baby.

2. Yinulo yilonta (fragrance oil), symbolizes personal fragrant hoped.

The requirements are prepared a day before the process. The event is started by speech and reading shalawat conducted by Imam (prayer leader), in local term called as hatibi. It is then continued by momonto custom (sticking turmeric mixed with whiting) to the baby and her parent. After momonto event, the mother and her daughter brought to the place of mopolihu lo limu event.

Mother and her baby are seated on grated coconut facing to east direction. First watering is by her mother represented by her grandmother, if the mother 
laps her baby. The second watering is by her father, both mother and father take water from the ingredient pan. The third watering is by custom handler or imam. The water is from yellow tube bamboo, it is the first tube. The second until seventh tube waterings will be done by hulango (village midwife). If grandfather and grandmother are still alive, then they have a right to watering water from the tube.

After bathing, the baby wear custom cloths, long dress decorated by golds flowers, and baby's head wear headband, the baby has been ready to circumcised. During mongubingo (female circumcision) process, the village midwife covers her body with alumbu moputi'o (white fabric), the baby will be smeared with yinula monu (fragrant ingredient) as symbol of after circumcised. The event will be continued by lunch together and drinking coffee/tea. Thus, all series of the female circumcision have been done.

Based on observation result, the tradition also functioned as family gathering involving neighboord and relative come from far area. Visitors and relative can take lesson and suggestion that described during female circumcision custom procession in Gorontalo.

The mongubingo custom that begun by mopolihu lo limu is a series of tradition that describes the hope of parent, family and Gorontalo people generally in order their daughter become soleha women and virtuous character. To make more meaning, the female circumcision is explained by parent to their children when the daughter entering into teenager time. Besides a series of custom process, the female circumcision describes the hope in order the daughter can grow to become noble morals women and emphasizes on her dignity as religious and civilized women.

The core is female circumsion giving profound message and teaching taken from Islamic teaching about the important of noble behavior values for women. Polite behavior and attitude will bring significant effect on household life to accompany husband, educate children and give considerable contribution for community and nation state life. The saliha women can accompany her husband in leading and teaching household, even if the husband has an occupation as patron and protector of people. If the occupation will be given to good women based on religion, then she will be able to create a trustworthy and responsible leadership situation.

The female circumcision oriented to build graceful and polite individual characters, who care to parent and loving, protecting to younger. Women are also demanded to avoid lousy attitude and behavior that can harm 
themselves and others, such as: stingy, say rude, arrogant, and look down on others (Sartin Djou, interview on November 27, 2018). It reflected the moral message in the form of prayer, hope and suggestion. The harmful practice should be avoided by every women that contained in mopolihu lo limu and mongubingo tradition is as follows:

1. Nene'alo, means annoying. The leader should avoid the annoying behavior, break religion norm, custom and national regulation of Indonesia.

2. Wetetolo, means speaking in lousy speech. The leader should be able to control their speaking. Every speaking should give useful for him/ herself and others, speaking right and valid.

3. Kekengolo, means to behave as if busy. Women with responsible as leader should be not to make busy for herself not giving useful for other. Every activity should be done based on worship.

4. Kureketolo, means to behave and speak carelessly.

5. Pa'ingolo, means she likes to deny her parent. Although, the women have occupation, she should accept suggestions from her parent as long as the idea is not contradicting with religion and the aplicable norm.

6. Bulabolo, means to cut speaking of others with a brag. The leader women should give occasion for other to speak. Hearing what deliveries by others or follower is the wise behavior before determing everything.

7. Hutatingolo, means speaking rudely. Ethic and politeness of leader, particularly women will seem from word or sentence expressed. More soft the sound of leader will be more showing their authority.

The responsibility of women starts from her family, community, and even broader. To realize commendable, noble, and dignified behavior are not an easy thing. It needs sincerity and tenacity to always learn both formal or informal education, even learning from experience is also very important to get values contained in cultural and custom that are not contradicting with religion. Cultural and tradition are the human thought result applied to social life. It provides message and meaning delivered to community about goals of cultural and custom intended. Beside learning from formal and informal educations, working hard and always praying become the primary key to make women as more dignified leader, professional, trusted and responsible. 


\section{Conclusion}

Gorontalo people are one of the tribe in Indonesia, they were born as Muslim that firmly hold on Islamic religion and emphasizing on custom and cultural values. Female circumcision custom started by bathing water of lime (mopolihu lo limu and mongubingo tradition) is one of the tradition preserved and maintained by Gorontalo people until now. Female circumcision in Gorontalo gives message for women, particularly those who have position and occupation always to avoid negative behavior as like described on circumcision procession activiy or meaning or symbol of cultural object used in female circumcision custom procession. The purpose intended is to remove contradictory trait and behavior with religion, custom and applicable norm for maintaining the female honor and self-identity.

\section{References}

Affiah, N. D. 2017. Islam, kepemimpinan perempuan, dan seksualitas. Yayasan Pustaka Obor Indonesia.

Ahmad, A. Potret Khusus Perilaku Korupsi Perempuan Pemimpin Daerah. https:// covesia.com/news/baca/83508/potret-khusus-perilaku-korupsi-perempuanpemimpin-di-daerah.

Amin, B. 2012. Memori Gorontalo, Teritori, Transmisi dan Tradisi. Yogyakarta: Ombak.

Amin, S. (2018). Teologi Perempuan: Menyejajarkan atau menyatukan? El Harakah (Terakreditasi), 3(1), 31-40

Arpin, A., \& Haritsa, H. 2018. Penyelesaian tindak pidana melalui mediasi penal oleh masyarakat desa di kabupaten Gorontalo. Jurisprudentie: Jurusan Ilmu Hukum Fakultas Syariah dan Hukum, 5(2), 44-66

Astuti, R. P. 2019. Optimalisasi pemberdayaan perempuan dalam kepemimpinan efektif. An-Nisa', 12(1), 101-119

Botutihe, M. \& Daulima, F. 2003. Tata Upacara Adat Gorontalo. Gorontalo: Galeri Budaya Daerah.

Djibu, F, Kobi, S., \& Katili, L.D. 2014. Makna dan nilai tradisi mopolihu lo limu pada masyarakat Gorontalo. KIM Fakultas Ilmu Sosial, 2(3)

el Harakah Jurnal Budaya Islam Vol. 22 No. 1 Tahun 2020 
Geotimes. 2017. Kepemimpinan perempuan di masa kini. https://geotimes.co.id/ opini/kepemimpinan-perempuan-di-masa-kini/

Inayati, I. N., Widanti, A., \& Lucyati, A. 2016. Ketentuan tentang sunat perempuan dikaitkan dengan asas gender dan nondiskriminatif. Soepra, 2(1), $61-73$

Isroqunnajah, I. (2008). Dorsumsisi, awal kekerasan terhadap perempuan? El Harakah (Terakreditasi), 3(1), 9-20

Jurdi, S. 2010 Sosiologi Islam E⿱ Masyarakat Modern. Jakarta: Kencana.

Khatijah. 2014. Khitan Laki-Laki Dan Perempuan Perspektif Empat Mazhab dan Medis. Thesis Universitas Islam Negeri Sultan Sarif Kasim Riau.

Khatijah. 2014. Khitan Laki-Laki dan Perempuan Perspektif Empat Mazhab dan Medis. Thesis. Universitas Islam Negeri Sultan Sarif Kasim Riau.

Khumairo. 2019, May 6th. https//www.wartaekonomi.co.id/read226514/ kepala-bappenas-tegaskan-peran-perempuan-dalam-pembangunanindonesia.html.

Maisarah, M. M. 2015. Polemik khitan perempuan: Tinjauan dari berbagai aspek. Jurnal Al-Huda, 7, 69-96

Makmur. 2009. Teori Manajemen Stratejik dalam Pemerintahan dan Pembangunan. Bandung: Refika Aditama.

Mufidah (2008). Perempuan dan keutuhan bangsa: Terikat atau merekat? El Harakah (Terakreditasi), 3(1), 100-111

Mustaqim, M. 2016. Konstruksi dan reproduksi budaya khitan perempuan: Pergulatan antara tradisi, keberagamaan dan kekerasan seksual di Jawa. Palastren Jurnal Studi Gender, 6(1), 89-106

Nashichuddin, A. 2010. Realitas Tradisi Khifadh di Masyarakat. Malang: UIN-Maliki Press.

Nofianti, L. 2016. Perempuan di sektor publik. Marwah: Jurnal Perempuan, Agama dan Jender, 15(1), 51-61

Peraturan Menteri Kesehatan RI Nomor 6 tahun 2014 tentang Sunat Perempuan. 2016. Diakses dari www.kesmas.kemenkes.go.id 
Poenk, S. 2016, October 3. Posisi dan Peran Perempuan dalam Pembangunan Bangsa http://rakyatbekasi.com

Prantiasih, A. 2016. Reposisi peran dan fungsi perempuan. Jurnal Ilmiah Pendidikan Pancasila dan Kewarganegaraan, 27(1), 1-6

Prasetya, H. A. 2019, November 16. Islam, Kepemimpinan Perempuan, dan Seksualitas https://www.kompasiana.com/hariansyahade/5dd002dfd 541df36361b7902/review-buku-islam-kepemimpinan-perempuan-danseksualitas

Samani, Muchlas \& Harianto. 2012. Konsep dan Model Pendidikan Karakter. Bandung: Remaja Rosdakarya.

Tombuu, A.K. 2011. Analisis kepemimpinan transformasional terhadap kualitas perencanaan pembangunan daerah. Thesis STIA LAN Makassar.

WHO International. 1997. Types of Female Genital Mutilation. https://www. who.int/sexual-and-reproductive-health/types-of-female-genital-mutilation 
